\title{
Econometric Modeling and Forecasting of Food Exports in Albania
}

Prof. Assoc. Dr. Alma Braimllari (Spaho)

Oltiana Toshkollari

University of Tirana, Albania, alma.spaho@unitir. edu. al, spahoa@yahoo.com

“Aleksandër Moisiu” University, Durrës, Albania; o. toshkollari@gmail. com

\begin{abstract}
Exports of goods and services represent one of the most important sources of foreign exchange income that alleviate the pressure on the balance payment and create employment opportunities. Exports' opportunities in Albania for food products have been increasing significantly, but still they are far from their real capacity. This study is an attempt to model and forecast the monthly export of food, beverages and tobacco products of Albania, using the seasonal autoregressive integrated moving average (SARIMA) methodology. The data used are covering the period 2005:M12015:M12, and are taken from the database of National Institute of Statistics of Albania. Unit root tests are used to test the stationarity of the series. Autocorrelation and partial autocorrelation functions are used to identify the most suitable SARIMA model, in explaining the time series and forecasting the future monthly food exports. The residuals of the best fitted model are used for the diagnostic checking. The results indicate that the best fitted model is SARIMA $(3,1,1) \times(1,1,0) 12$. The best identified model for the data in the study is used to forecast monthly food exports up to the year 2017. These findings are useful for customers, producers and policymakers.
\end{abstract}

Keywords: stationarity, trend, unit root test, seasonality, SARIMA methodology.

\section{Introduction}

Trade is an important part of the total development effort and national growth of all economies including Albania. Exports of goods and services represent one of the most important sources of foreign exchange income that ease the pressure on the balance payment and create employment opportunities. Albania's geographical location offers a trade potential, especially with the European Union market and the free trade agreements with all Balkan countries have created opportunity for trade development all over the region. During the last years exports in Albania indicate an increase and the food exports as well, although the imports are higher than exports.

Exports' opportunities in Albania for food products have been increasing significantly, but still they are far from their real capacity. Mainly due to lack of marketing facilities (storage, processing, packing of products), low standards related to food safety, low level of competiveness in the market of Albanian food products due to low quality and relatively high cost of the Albanian products, and deficiency and low levels of food production and industry (Bezhani, 2013).

Prediction is very important for decision making in food industry. The decision making in this industry involves planning of uncertainty, finding of the optimal level of production and even strategic planning for capacity expansion. The cost of underestimation or overestimation can be very high; therefore, accurate forecasts are very important. Accurate short-term forecasts are considered necessary by producers, clients and customers particularly during the periods with the highest demand. Seasonal autoregressive integrated moving average (SARIMA) methodology can be applied to model and to forecast the exports and imports of food products.

SARIMA methodology has been applied for modeling and forecasting of exports of products from several countries. Faroogi (2014) using the yearly data of Pakistan exports for the period 1947-2013, fitted the ARIMA $(1,2,2)$ model to forecast the 
exports with the lower value of AIC. Shitan et al (2012), proposed the SARIMA $(1,1,0) \times(0,1,1) 12$ to model Bangladesh export values based on the $\mathrm{AlC}_{\mathrm{c}}$ criterion after differencing at lags 12 and 1 and then subtracted the mean of the differenced series. Paul et al (2013), using the data of meat exports from India for the period November 1992 to December 2011 and after one non-seasonal and one-seasonal differencing to the original time-series, found the $\operatorname{SARIMA}(2,1,0) \times(1,1,0)_{12}$ model to best fits to the original data.

In this study, SARIMA methodology has been applied for modeling and forecasting of monthly export of food, beverages and tobacco products from Albania. The Akaike's Information Criteria is used to select the best model that fits to the data and the best identified model was used for forecasting monthly food exports up to the year 2017.

\section{Materials and Methods}

The time series models are used in this paper to model food exports. Stationarity is required for fitting a time-series into SARIMA framework. A time series is called stationary if the mean, variance, and covariance of the underlying series do not depend on time (time invariant). To determine the stationarity, the time plot, autocorrelation function (ACF) and partial autocorrelation function (PACF) can be used as a first attempt. The Augmented Dickey Fuller (ADF) unit roots test can be used to detect the stacionarity of a time series. The ADF unit roots test performs a regression model of the form

$$
\Delta X_{t}=\alpha_{0}+\alpha_{1} t+\rho X_{t-1}+\sum_{i=1}^{m} \beta_{i} \Delta X_{t-i}+u_{t}
$$

where $\mathrm{m}$ indicate the lag order, and $\Delta X_{t}=X_{t}-X_{t-1}$. The null hypothesis is: the time series $\left\{\mathrm{X}_{\mathrm{t}}\right\}$ has a unit root or the series is not stationary ( $\mathrm{HO}: \rho=0$ and $\mathrm{Ha}: \rho<0)$. If the $\mathrm{p}$ value is less or equal to $5 \%$, the null hypothesis is rejected and is concluded that the series is stationary.

When a time series is not stationary usually non seasonal and seasonal differencing at the appropriate lag can be applied to achieve stationarity.

The multiplicative seasonal autoregressive integrated moving average model is given by

$$
\phi(B) \Phi\left(\mathrm{B}^{s}\right)(1-B)^{d}\left(1-B^{s}\right)^{D} X_{t}=\theta(B) \Theta\left(\mathrm{B}^{s}\right) Z_{t}
$$

where $\left\{Z_{t}\right\}$ is a sequence of uncorrelated random variables with zero mean and constant variance $\sigma^{2}$ (white noise), $s$ is the seasonal period, $\mathrm{B}$ is the backward shift operator $\left(\mathrm{B}^{\mathrm{k}} \mathrm{X}_{\mathrm{t}}=\mathrm{X}_{\mathrm{t}-\mathrm{k}}\right.$ and $\left.\mathrm{B}^{\mathrm{k}} \mathrm{Z}_{\mathrm{k}}=\mathrm{Z}_{\mathrm{t}-\mathrm{k}}\right), \phi(B)=1-\phi_{1} B-\cdots-\phi_{p} B^{p}$, $\theta(B)=1+\theta_{1} B+\cdots+\theta_{q} B^{q}, \quad \Phi\left(B^{s}\right)=1-\Phi_{1} B^{s}-\cdots-\Phi_{P} B^{P s} \quad$ and $\Theta\left(B^{s}\right)=1+\Theta_{1} B^{s}+\cdots+\Theta_{Q} B^{Q s} \quad$ (Brockwell and Davis, 2002; Shumway and Stoffer, 2006).

The Akaike's Information Criterion (AIC) is useful for determining the order of an SARIMA model, and it can be written as

$$
A I C=-2 \log (L)+2 k
$$

where $L$ is the maximum likelihood for an SARIMA model, $k$ is the number of estimated parameters in the model (including $\sigma^{2}$, the variance of the residuals). For small sample sizes, that is, if $n / k$ is less or equal to 40 , the corrected AIC should be used instead:

$$
A I C_{C}=-2 \log (L)+\frac{2 k n}{n-k-1}
$$

where $\mathrm{n}$ is the sample size after differencing. The good models are obtained by minimizing either the AIC or AICc value. 
The residuals of the best fitted model are used for the diagnostic checking. The Ljung-Box test is used to the residuals to determine if the residuals are random and that the model provides an adequate fit to the data in the study.

In order to evaluate the performance of the best model are used the Mean Absolute Error (MAE), Root Mean Square Error (RMSE) and the Mean Absolute Percentage Error (MAPE), defined respectively by the following equations:

$$
M A E=\frac{1}{n} \sum_{i=1}^{n}\left|y_{i}-\hat{y}_{i}\right| \quad R M S E=\sqrt{\frac{1}{n} \sum_{i=1}^{n}\left(y_{i}-\hat{y}_{i}\right)^{2}} \quad M A P E=\frac{1}{n} \sum_{i=1}^{n} \frac{\left|y_{i}-\hat{y}_{i}\right|}{y_{i}} \cdot 100 \%
$$

The food exports data used in this study, measured in ALL million, are covering the period 2005:M1-2015:M12, and are taken from the database of National Institute of Statistics of Albania. Food exports comprise the commodities in these four sections: live animals and animals' products; vegetables products; edible oils; and prepared foodstuffs, beverages and tobacco.

$\mathrm{R}$ statistical package is used to analyze and model the monthly food exports data.

\section{Results and Discussion}

The value of total exports from Albania is increased during the period under study, and the value of food exports is also increased. The percentage of monthly food exports to total exports in Albania are shown in figure 1. The lowest percentage of food exports to total exports was in January 2011, 5. 68\%; whereas the highest percentage was in August 2005 and October 2015 , respectively with $13.14 \%$ and $13.07 \%$.

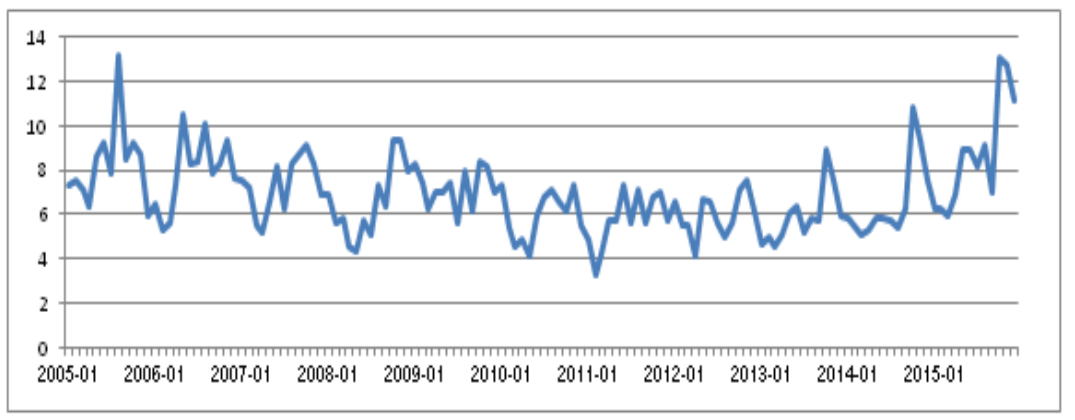

Figure 1. Food exports as a percentage of total exports

The figure 2 shows the value of food exports by sections, and the prepared foodstuffs, beverages and tobacco, and vegetables products have dominated the two other sections. From 2005 to 2010 the exports of prepared foodstuffs, beverages and tobacco has dominated the other three sections, whereas from 2011 to 2015 the exports of vegetables products has dominated the other sections. 


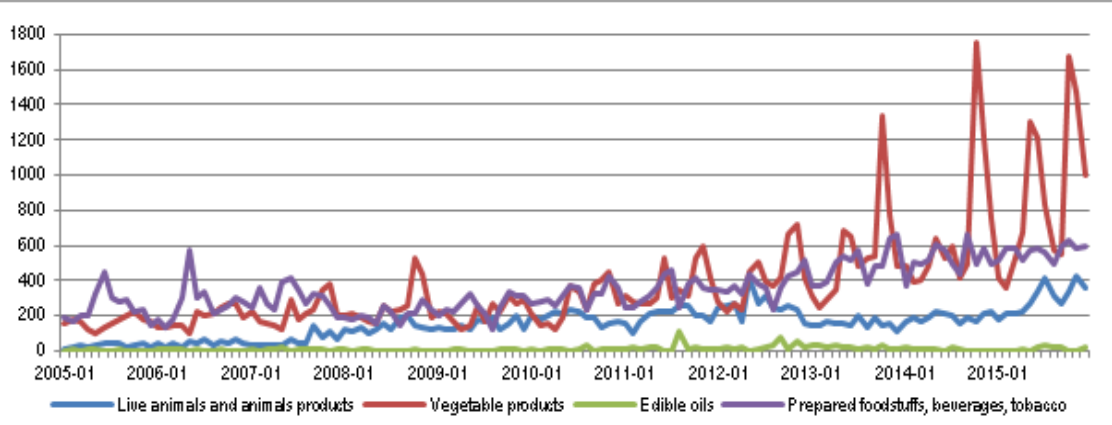

Figure 2. Food exports by sections

The main partners of food exports from Albania, during the period under study are: Italy, Kosovo, Greece and Germany. Food exports from Albania to Italy have dominated with more than one third of total food exports during the period under study. More specifically, during year 2015, main partners were Italy with $32,7 \%$ of total food exports, followed by Kosovo with about $11 \%$, Greece with $10 \%$ and Germany with $5.7 \%$ of food exports.

The food exports plot for the period 2005-2015 in figure 3 shows that the food exports are increased from year to year. Since 2005, the food exports is increased nearly by 4 times. The smaller value was in February 2006 and the biggest in October 2015.

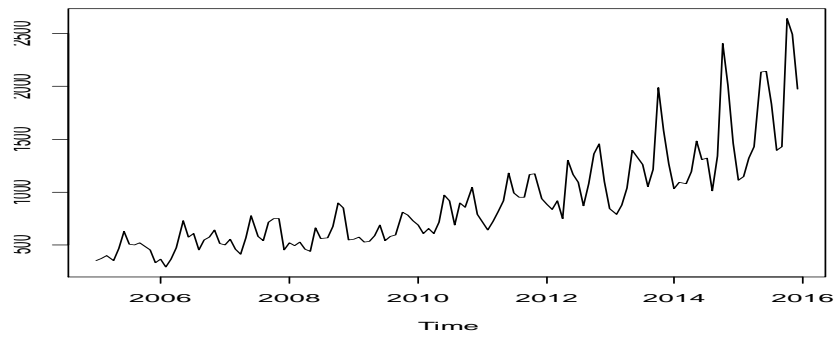

Figure 3. Food exports time series

The figure 4 shows the monthly plot of the data and also a positive trend of food exports during years for all months. The highest values of average food exports were in October and November, and the lowest values in February and January.

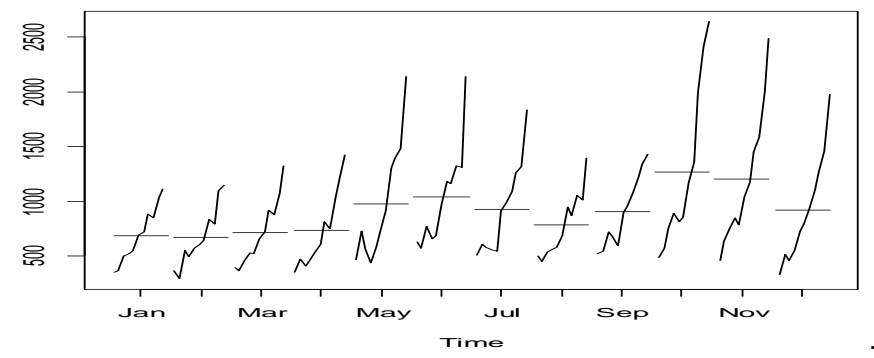

Figure 4. Food Exports by month 
The ACF and PACF plots of the food exports series, in figure 1 in Appendix, show that the series is not stationary. The ADF test statistics for the food exports series was found to be -2.567 (lag order $=5$ ), $p=0$. 34, so the null hypothesis of unit root cannot be rejected at $5 \%$ level, indicating that the food exports series is not stationary.

To achieve the stationarity of the food exports series, a non seasonal differencing at lag 1 and a seasonal differencing at lag 12 is applied to the original series. The ADF test statistics for the differenced series was found to be -22.55 (lag order $=4), p<1 \%$, so the series is stationary. The plot of the differenced food exports series and also the respective ACF and PACF plots are shown in figure 2 in Appendix.

Many possible models are considered. In the table 1 are shown several estimated model and their respective $\mathrm{AIC}_{\mathrm{c}}$ value.

Table 1. Some SARIMA estimated models and their respective $\mathrm{AIC}_{\mathrm{c}}$ value

\begin{tabular}{|l|l|l|l|}
\hline Model & AlC $_{c}$ & Model & AlC $_{c}$ \\
\hline SARIMA $(3,1,1) \times(0,1,1)_{12}$ & 1513. & SARIMA $(3,1,1) \times(0,1,0)_{12}$ & 1518. \\
& 72 & & 47 \\
\hline SARIMA $(3,1,1) \times(1,1,1)_{12}$ & 1515. & SARIMA $(0,1,2) \times(0,1,1)_{12}$ & 1518. \\
& 59 & & 19 \\
\hline SARIMA $(3,1,1) \times(1,1,0)_{12}$ & 1513. & SARIMA $(1,1,0) \times(0,1,1)_{12}$ & 1537. \\
& 35 & & 63 \\
\hline
\end{tabular}

The best fitted model was the SARIMA $(3,1,1) \times(1,1,0)_{12}$ model with the lower AIC $c$ value of 1513.72 and the value of Log likelihood of -750. 3. The results of the best model are shown in table 2 .

Table 2. Results of SARIMA $(3,1,1) \times(1,1,0) 12$ model

\begin{tabular}{|l|l|l|}
\hline Variable & Coefficient & Standard error \\
\hline AR1 & 0.245 & 0.110 \\
\hline AR2 & -0.009 & 0.100 \\
\hline AR3 & -0.280 & 0.097 \\
\hline MA1 & -0.798 & 0.085 \\
\hline Seasonal AR1 & -0.280 & 0.100 \\
\hline Sigma $^{2}$ & 17211 \\
\hline
\end{tabular}

The results of ADF test for the best fitted model residuals indicated a ADF value of -5.08 , lag order $=5$ and $p$-value $<1 \%$, so the residuals series is stationary. The ACF and PACF plots of the residuals up to 30 lags, shown in figure 3 in Appendix, indicated that none of the autocorrelations was significant at $5 \%$ level. This confirms that the selected SARIMA model was an appropriate model for forecasting the food exports, which also indicated the 'good fit' of the model.

The results of Ljung-Box test indicated a value of statistics of 27.98 ( $d f=28)$, and $p$-value $=0.465>5 \%$, that is the model is appropriate for the data. The standartized residuals plot and p-values for Ljung-Box statistics are shown in figure 4 in Appendix. The results of Lagrange Multiplier (LM) test for autoregressive conditional heteroscedasticity (ARCH) test, with null hypothesis: no ARCH effects of best fitted SARIMA model, indicated a chi-squared value of $20.8, \mathrm{df}=12$ and $p$-value $=0.054$. To evaluate the performance of the best fitted model, are found the values of MAE $=83.59$, RMSE $=124.56$, and MAPE $=9.57 \%$.

The figure 5 shows the actual values food exports for the period under study and the forecasted values of monthly food exports for years 2016 and 2017 based on the best fitted model. 


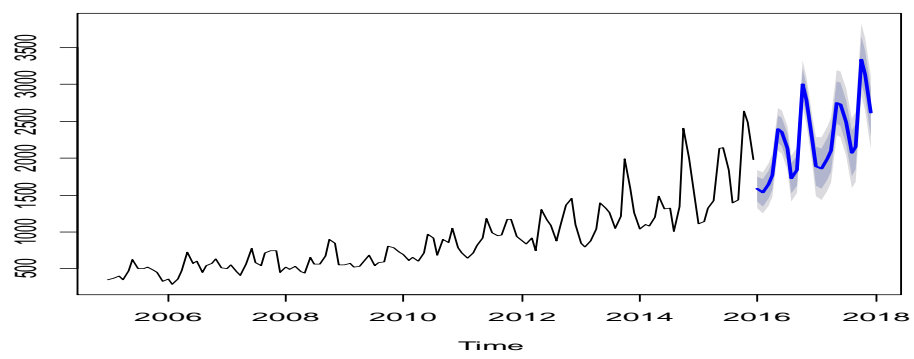

Figure 5. Predicted food exports (blue line) from SARIMA $(3,1,1) \times(1,1,0) 12$ model

The forecasted values of monthly exports are very important for customers, producers and policymakers as exports are an important source of foreign exchange income and create job opportunities. The forecasted values of monthly food exports for 2016 and 2017, and their corresponding lower and upper $95 \%$ confidence interval limits are given in table 3 .

Table 3. Predicted monthly food exports for years 2016 and 2017

\begin{tabular}{|c|c|c|c|c|c|c|c|}
\hline Year 2016 & Forecast & $\begin{array}{l}\text { Lower } \\
\text { limit }\end{array}$ & $\begin{array}{l}\text { Upper } \\
\text { limit }\end{array}$ & Year 2017 & Forecast & $\begin{array}{l}\text { Lower } \\
\text { limit }\end{array}$ & $\begin{array}{l}\text { Upper } \\
\text { limit }\end{array}$ \\
\hline January & 1582. 98 & $\begin{array}{l}1325 . \\
85\end{array}$ & $\begin{array}{l}1840 . \\
11\end{array}$ & January & 1887. 27 & $\begin{array}{l}1488 . \\
00\end{array}$ & $\begin{array}{l}2286 . \\
55\end{array}$ \\
\hline February & 1532. 00 & $\begin{array}{l}1250 . \\
27\end{array}$ & $\begin{array}{l}1813 . \\
73\end{array}$ & February & 1858. 85 & $\begin{array}{l}1437 . \\
80\end{array}$ & $\begin{array}{l}2279 . \\
90\end{array}$ \\
\hline March & 1642. 25 & $\begin{array}{l}1349 . \\
94\end{array}$ & $\begin{array}{l}1934 . \\
56\end{array}$ & March & 1987. 40 & $\begin{array}{l}1552 . \\
98\end{array}$ & $\begin{array}{l}2421 . \\
82\end{array}$ \\
\hline April & 1769. 58 & $\begin{array}{l}1477 . \\
26\end{array}$ & $\begin{array}{l}2061 . \\
90\end{array}$ & April & 2107. 35 & $\begin{array}{l}1670 . \\
20\end{array}$ & $\begin{array}{l}2544 . \\
50\end{array}$ \\
\hline May & 2391.15 & $\begin{array}{l}2098 . \\
24\end{array}$ & $\begin{array}{l}2684 . \\
06\end{array}$ & May & 2753. 98 & $\begin{array}{l}2312 . \\
31\end{array}$ & $\begin{array}{l}3195 . \\
65\end{array}$ \\
\hline June & 2357.59 & $\begin{array}{l}2062 . \\
62\end{array}$ & $\begin{array}{l}2652 . \\
55\end{array}$ & June & 2731.38 & $\begin{array}{l}2283 . \\
48\end{array}$ & $\begin{array}{l}3179 . \\
29\end{array}$ \\
\hline July & 2135.99 & $\begin{array}{l}1834 . \\
82\end{array}$ & $\begin{array}{l}2437 . \\
18\end{array}$ & July & 2486.06 & $\begin{array}{l}2028 . \\
51\end{array}$ & $\begin{array}{l}2943 . \\
61\end{array}$ \\
\hline August & 1725. 62 & $\begin{array}{l}1418 . \\
24\end{array}$ & $\begin{array}{l}2033 . \\
01\end{array}$ & August & 2067. 94 & $\begin{array}{l}1600 . \\
82\end{array}$ & $\begin{array}{l}2535 . \\
06\end{array}$ \\
\hline September & 1835.17 & $\begin{array}{l}1522 . \\
59\end{array}$ & $\begin{array}{l}2147 . \\
76\end{array}$ & September & 2155.89 & $\begin{array}{l}1680 . \\
03\end{array}$ & $\begin{array}{l}2631 . \\
75\end{array}$ \\
\hline October & 3005.58 & $\begin{array}{l}2689 . \\
28\end{array}$ & $\begin{array}{l}3321 . \\
88\end{array}$ & October & 3337.44 & $\begin{array}{l}2854 . \\
10\end{array}$ & $\begin{array}{l}3820 . \\
78\end{array}$ \\
\hline November & 2787.65 & $\begin{array}{l}2467 . \\
99\end{array}$ & $\begin{array}{l}3107 . \\
30\end{array}$ & November & 3138.68 & $\begin{array}{l}2648 \\
26\end{array}$ & $\begin{array}{l}3629 . \\
10\end{array}$ \\
\hline December & 2267.91 & $\begin{array}{l}1944 . \\
82\end{array}$ & $\begin{array}{l}2590 . \\
99\end{array}$ & December & 2620.88 & $\begin{array}{l}2123 . \\
38\end{array}$ & $\begin{array}{l}3118 . \\
38\end{array}$ \\
\hline
\end{tabular}

The highest value of food exports is predicted to be in October, respectively with value of $3005.58 \mathrm{ALL}$ million in 2016 and 3337. 44 in 2017, whereas the lowest value in February, respectively 1532 and 1858. 85 ALL million for the two coming years. 


\section{Conclusions}

Exports are a very important factor to reach a sustainable economic development. The importance of increasing exports is not related only with the reduction of trade balance, but also with the improvement of the quality of products and the increase of the production capacity, new jobs creation, and the wellbeing. The increase of quality of Albanian products will have a positive impact on exports and food exports growth.

This study is a first attempt to model the monthly food exports in Albania for the period 2005-2015 and to forecast the monthly food export for years 2016 and 2017 using SARIMA methodology. Fluctuations in the value of food exports are a matter of concern for customers, producers and policymakers.

The results of the descriptive analysis indicated that the percentage of food exports to total exports varied from $5.68 \%$ in January 2011 to $13.14 \%$ in August 2005. The food exports are increased from 2005 to 2015 and are dominated by two sections: the prepared foodstuffs, beverages and tobacco; and vegetables products.

The food exports time series indicated a positive trend and seasonality. Monthly food exports of Albania is found to follow the SARIMA $(3,1,1) \times(1,1,0) 12$ with an AICc value of 1513. 72. This model was used to forecast the monthly Food Exports for year 2016 and 2017. The highest predicted value of food exports is 3005.58 ALL million in October 2016 and the lowest value 3337. 44 in February 2016.

To increase food exports from Albania is necessary the improvement of the infrastructure in rural areas that obstructs the arrival of products to the market, to increase the state subventions for producers and farmers because the level of loans for investments is still low in this sector, and to achieve the Europian Union standards of food products. Increasing the quality of food products is the most important factor for improving the competiveness. Technological advancement and new methods for management of production systems will encourage the growth of production of food products.

In the future research, the relationships between food exports, foreign direct investments and exchange rate ALL/euro can be studied using econometric models.

\section{References}

Bezhani, E. (2013). The economic impact of agricultural products in the Albanian products. Academic Journal of Interdisciplinary Studies, Vol 2, No1, pp 263-268.

Brockwell, P. J. and Davis, R. A. (2002)

Introduction to Time Series and Forecasting, second edition, Springer-Verlag, New York.

Farooqi, A. (2014). ARIMA model building and forecasting on Imports and Exports of Pakistan. Pakistan Journal of Statistics and Operations Research, Vol X, No 2, pp 157-168.

Paul, R. K., Panwar, S., Sarkar S. K., Kumar, A., Singh, K. N., Faroogi S., and Choudhary V. K. (2013). Modelling and Forecasting of Meat Exports from India. Agrcultural Economics Research Review, Vol. 26, No. 2, July-December, pp 249255.

Shitam, M., Hossian, M. M., and Rajeb, M. (2012). A re-analysis of time series modeling of Bangladesh Export values. International Journal of Statistical Sciences, Vol. 12, pp 79-88.

Shumway, H. R. and Stoffer, S. D. (2006). Time Series Analysis and Its Applications with R examples. Second edition, Springer-Verlag New York. 


\section{Appendix}

Figure 1. The ACF and PACF of the original food exports series
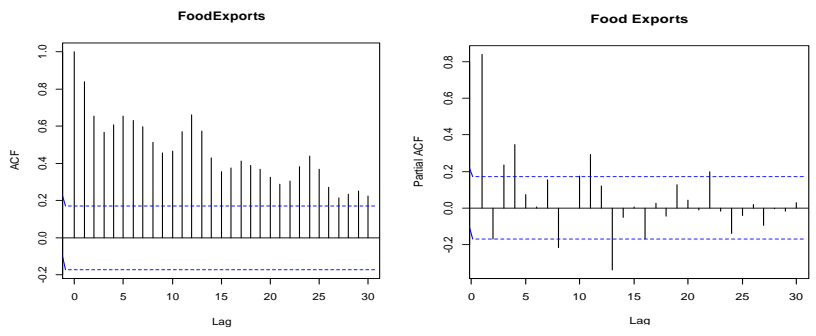

Figure 2. The plot of food exports series after differencing at lag 1 and 12, and the ACF and PACF plots
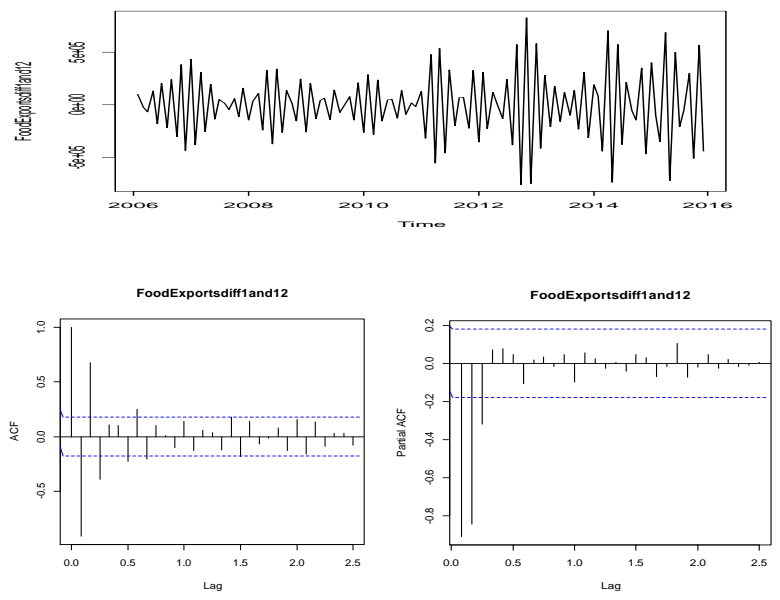

Figure 3. The ACF and PACF plots of residuals series
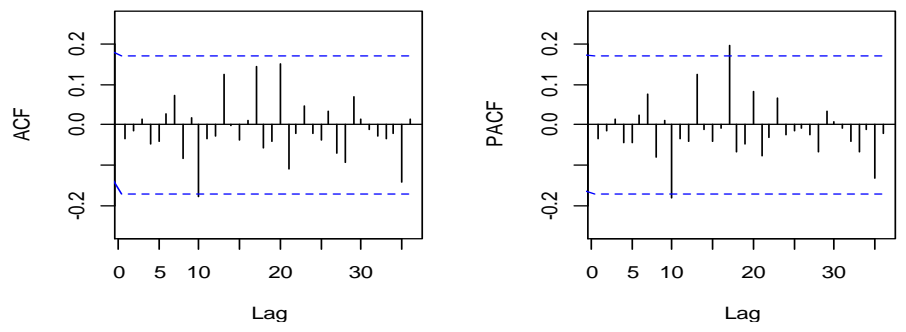
Figure 4. The standartized residuals plot and the plot of $p$-values for Ljung-Box statistics

Standardized Residuals

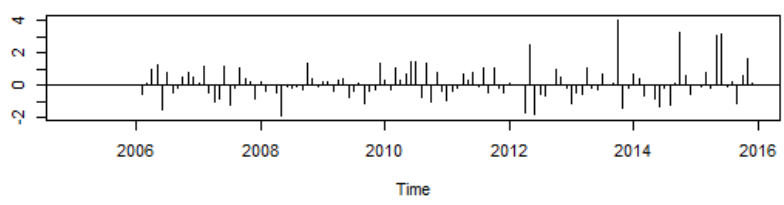

p values for Ljung-Box statistic

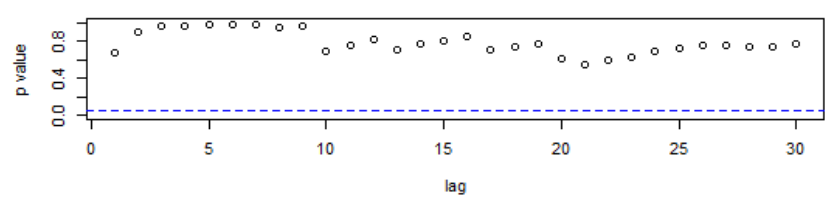

